\title{
METHOD OF MEASURING LIQUID WATER MASS FRACTION OF SNOW BY ALCOHOL SOLUTION
}

\author{
By D. FISK \\ (U.S. Army Cold Regions Research and Engineering Laboratory, Hanover, \\ New Hampshire 03755-1290, U.S.A.)
}

ABSTRACT. A method of making field measurements of the liquid water fraction of snow has been developed in which a snow sample is dissolved in methanol to produce a temperature depression. The depression is linearly related to the liquid water content of the snow sample. A single operator can perform four to five measurements per hour with a maximum absolute error of $1.0 \%$.

RÉsumé. Une méthode de mesure de la teneur en eau liquide de la neige par solution d'alcool. Une méthode de mesure de terrain de la teneur en eau liquide de la neige a été développée en dissolvant l'échantillon de neige dans du méthanol pour produire un abaissement de température. L'abaissement est linéairement proportionnel à la teneur en

\section{INTRODUCTION}

The alcohol calorimetric method of measuring the liquid water content of snow was developed as an alternative to the freezing and melting calorimetric methods. Freezing calorimetry (Jones and others, 1983), while in theory quite accurate, has high potential for poor heat transfer between the solid snow sample and the cold freezing agent, causing inconsistent measurements. It requires an operator with high levels of skill and dedication, and is very slow. Melting calorimetry (Yosida, 1967) has the advantage of consistently good heat transfer from the hot water to the snow and is faster than freezing calorimetry, but Colbeck (1978) showed that it is inherently inaccurate.

In alcohol calorimetry, the snow sample is completely dissolved in methanol so that the heat-transfer problem of freezing calorimetry is eliminated. The absolute accuracy of alcohol calorimetry is $1.0 \%$, as good as freezing and better than melting calorimetry, it is faster than either, and the required calculations are simpler. The present equipment uses only a $25 \mathrm{~g}$ snow sample, but equipment could easily be built to use a larger sample.

\section{THEORY}

The solution of a solid in a liquid can be considered a two-step phenomenon: the breaking of the solid's intermolecular forces, followed by the dispersion of its molecules or ions into the liquid solvent. The first step requires energy: the theoretical heat of fusion of the solid at its temperature. The second step releases energy: the heat of solution of the liquid solute in the solvent at their temperature (Steiner, 1948).

For many mixtures (e.g. $\mathrm{NaCl}$ and water), the energy changes associated with each step are approximately equal, so that net temperature changes are small. But the heat of fusion of ice is significantly larger than the heat of solution of the same mass of water in methanol, so there can be a large temperature change associated with dissolving ice in methanol. This provides a means of differentiating between eau de l'échantillon de neige. Un seul opérateur peut réaliser quatre à cinq déterminations à l'heure avec une erreur absolue maximum de $1 \%$.

Zusammenfassung. Eine Methode zur Messung des Massenanteils flüssigen Wassers im Schnee mit Hilfe einer Alkohollösung. Für Feldmessungen des Anteils an flüssigem Wasser im Schnee wurde eine Methode entwickelt, bei der zur Erzeugung einer Temperaturabnahme eine Schneeprobe in Methanol aufgelöst wird. Die Abnahme ist linear vom Wassergehalt der Schneeprobe abhängig. Ein einzelner Beobachter kann pro Stunde 4-5 Messungen mit einem maximalen Fehler von $1 \%$ durchführen. ice and water in snow; when a snow sample is dissolved in methanol, a temperature depression occurs which is proportional to the ice content of the snow.

\section{EQUIPMENT}

The solution of the snow in methanol takes place in the reaction cup (a) of the calorimeter (Fig. 1). The cup is

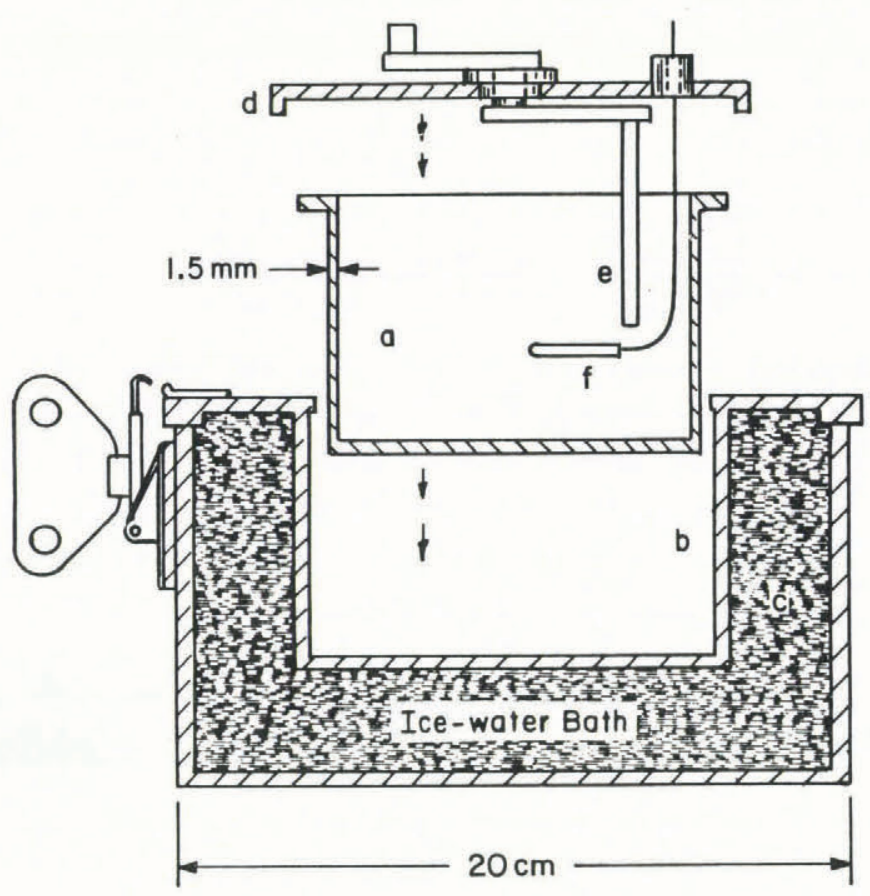

Fig. 1. Polycarbonate calorimeter for measurement of the liquid water content of snow: (a) reaction cup, (b) air space, (c) ice-water bath, (d) reaction-cup cover, (e) stirrer, $(f)$ resistance temperature detector. 
surrounded by an air space (b) which is in turn surrounded by an ice-water bath (c). The air space around the reaction cup and the cup's low mass allow a large temperature change in the snow-methanol mixture. The ice-water bath around the cup helps to prevent phase changes in the snow during sample weighting. The reaction-cup cover (d) holds the stirrer (e) and a platinum resistance temperature detector (RTD) (f).

The temperature of the mixture is displayed digitally with resolution of $0.1^{\circ} \mathrm{C}$ or $0.1^{\circ} \mathrm{F}$. Masses of snow and alcohol are measured on an electronic balance with resolution of $0.01 \mathrm{~g}$.

\section{PROCEDURE}

To eliminate corrections which would be necessitated by variations in the amounts of snow and methanol used, each is weighed as closely as possible to the masses used in calibrating the calorimeter, $25.0 \mathrm{~g}$ snow and $80.0 \mathrm{~g}$ methanol. This mass ratio also assures that the snow will dissolve completely.

The calorimeter, less the cover (d, e, and f), is placed on the balance and its weight is tared. While the cover is stored in a $0^{\circ} \mathrm{C}$ environment, $25.0 \mathrm{~g}$ snow is spooned into the reaction cup as quickly as possible. The snow is sampled and handled only with utensils which have been stored in the snow adjacent to the sample site.

A pre-weighed mass of methanol, which has been stored in a sealed flask in a separate ice-water bath, is then added to the snow sample. In weighing the methanol, compensation is made for the fact that a small amount will remain in the flask after pouring. At the instant the methanol contacts the snow, a stopwatch is started. The cover is returned to the calorimeter and the mixture is stirred gently.

Every $30 \mathrm{~s}$ for $6-8 \mathrm{~min}$ (depending on snow grain-size), the temperature of the mixture is recorded. A plot of temperature versus time yields a curve such as that shown in Figure 2. The part up to minute 4 of this particular curve corresponds to the period when the ice in the snow sample is dissolving. The linear part from minute 4 to minute 7 corresponds to the warming of the resulting methanol-water solution by the environment. (This part of the curve is not exactly linear because the rate of warming decreases as the solution temperature approaches the ambient temperature. However, correlation between the points and the regression is consistently about 0.99.) A longer measurement period is required for coarse-grained snow, which dissolves more slowly than fine-grained snow.

By extrapolating back from the positively sloped part

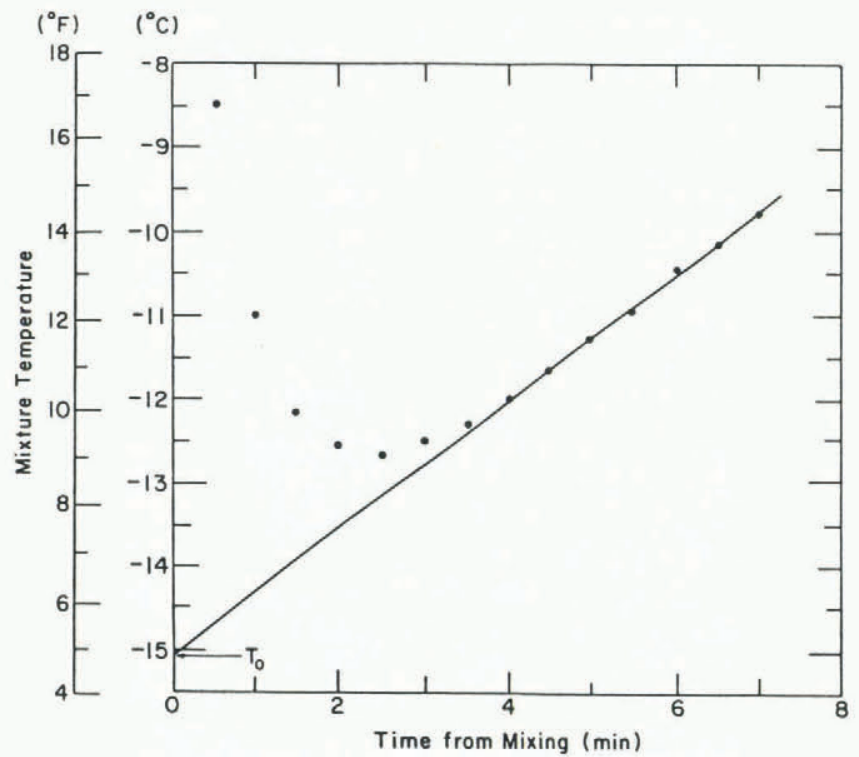

Fig. 2. Typical plot of mixture temperature for alcohol calorimeter test. of the curve, the theoretical temperature $T_{0}$ can be found. $T_{0}$ is the temperature which would be expected if the snow had dissolved instantly on addition of the methanol. Since the snow and methanol masses are constant and all components and equipment start at $0^{\circ} \mathrm{C}$, the liquid water fraction of the snow's mass is the only variable. The heat of solution of the "dissociated" snow ( $25 \mathrm{~g}$ water) in methanol at $0^{\circ} \mathrm{C}$ remains constant, but the energy required to dissociate the ice varies linearly with the amount of ice present. The energy for the dissociation process is obtained from a decrease in the temperature of the methanol-water solution. So the temperature $T_{0}$ of the solution is linearly related to the liquid water fraction of the snow.

\section{CALIBRATION}

Calibration is done by determining $T_{0}$ values for measurements on $25 \mathrm{~g}$ dry snow at $0^{\circ} \mathrm{C}$ and on $25 \mathrm{~g}$ water at $0^{\circ} \mathrm{C}$. These values, $T_{0 \mathrm{i}}$ and $T_{0 \mathrm{w}}$, represent the extremes of the liquid water-content range $(0-100 \%)$. Intermediate liquid water values can easily be calculated by the formula

$$
L_{\mathrm{m}}=\frac{T_{0}-T_{0 \mathrm{i}}}{T_{0 \mathrm{w}}-T_{0 \mathrm{i}}}
$$

where $L_{\mathrm{m}}=$ mass liquid water fraction.

With the present equipment, this formula is (temperatures are measured in ${ }^{\circ} \mathrm{F}$ for better resolution)

$$
L_{\mathrm{m}}=\frac{T_{0}-2.1}{46.4-2.1} .
$$

This gives a resolution of about $0.2 \% L_{\mathrm{m}}$.

\section{ERRORS}

Analysis indicates that worst-case errors in measurement of the masses of snow and methanol and in dispensing the methanol result in $T_{0}$ errors of $0.1^{\circ} \mathrm{F}$ (Steiner, 1948). The worst-case error in temperature measurement is $0.3^{\circ} \mathrm{F}$. Together, these errors limit the accuracy of $L_{\mathrm{m}}$ to $1.0 \%$ or about $0.3 \%$ volume liquid water content. Decreasing temperature-measurement errors by one-half would reduce $T_{0}$ error to $0.25^{\circ} \mathrm{F}$ and $L_{\mathrm{m}}$ error to $0.6 \%$ and $0.2 \%$ by volume.

\section{CONCLUSION}

Alcohol calorimetry has been used in the field since 1981 (Aitken, 1982). It works equally well with fine- and coarse-grained snow. The low sample mass allows measurements on thin layers or small areas of the snow. Measurements can be made by one operator at the rate of four or five per hour, including calculations. The procedure is easy to learn and requires little specialized equipment. Its reliability and accuracy make it an attractive means of measuring the liquid water content of snow.

\section{REFERENCES}

Aitken, G.W., ed. 1982. SNOW-ONE-A data report. CRKEL Special Report $82-8$, p. 567.

Colbeck, S.C. 1978. The difficulties of measuring the water saturation and porosity of snow. Journal of Glaciology, Vol. 20, No. 82, p. 189-201.

Jones, E.B., and others. 1983. Snowpack liquid water determinations using freezing calorimetry, by E.B. Jones, A. Rango, and S. Howell. Nordic Hydrology, Vol. 14, No. 3 , p. $113-26$.

Steiner, L. 1948. Introduction to chemical thermodynamics. Second edition. New York, McGraw-Hill.

Yosida, Z. [Yoshida, J.] 1967. Free water content of wet snow. (In Öura, H., ed. Physics of snow and ice: International Conference on Low Temperature Science ... 1966 ... Proceedings, Vol. 1, Pt. 2. [Sapporo], Institute of Low Temperature Science, Hokkaido University, p. 773-84.) 